\title{
THE EFFECT OF INCREASED LABOR FORCE PARTICIPATION OF MARRIED WOMEN ON THE DISTRIBUTION OF FAMILY INCOME IN THE NETHERLANDS
}

\section{INTRODUCTION}

The participation of married women in the labor force in The Netherlands has increased very rapidly over the last few decades. In 1962 the number of married women with sources of own income was scarcely 18 percent of the total number of married women. By 1981 this figure had grown to over 40 percent. As a result, the wives' proportion of family income has risen. In 1962 the wives' proportion of family income was barely 4 percent, whereas this figure had increased to more than 12 percent by $1981 .^{1}$

Although wives' participation in the labor force in The Netherlands lags behind the situation in neighboring countries, the situation described above does raise the question of how this development affects the distribution of family income and especially its inequality. The reason for this is that labor force participation and the wife's proportion of family income (excluding childrens' income) vary greatly from one income group to the other. The same is true of the development of wives' incomes. In the literature one cannot find an unequivocal answer to the above question. Both empirical and theoretical investigations give different answers. ${ }^{2}$ This uncertainty is closely linked to the fact that, especially in the sixties, there was an inverse relationship between the wife's decision to start working and the number of hours she wished to work

* The author is affiliated with the Department of Sociology, Tilburg University, P.O. Box 90153, 5000 LE Tilburg, and the Department of Economics, Erasmus University Rotterdam, P.O. Box 1738, 3000 DR Rotterdam, The Netherlands. The research was carried out in the framework of the project entitled 'Problems relating to the distribution of social security.' The author wishes to thank Professor A. Kapteyn and two anonymous referees for their helpful comments on an earlier draft of this paper.

1 These percentages are based on pre-tax income; see Grubben (1986b), p. 18, text-table 6.

2 See for example Betson and Van der Gaag (1984), Bergmann, Radlinski Devine, Gordon, Reedy, Sage and Wise (1980), Danziger (1980) and Thurow (1975). More specific for The Netherlands are Odink and Pott-Buter (1982), De Kam, Pommer and Wiebrens (1982) and Grubben (1986b). 
(and hence the income) on the one hand and the husband's income on the other hand. This relationship has subsequently weakened. The last few decades, however, theory has reached the conclusion that the observed equalizing effect of wives' income on the distribution of family income should diminish.

Using data for The Netherlands for the years 1962, 1967, 1970, 1975 and $1981,{ }^{3}$ we will try to ascertain how the income inequality of married couples is affected by the wives' income.

We will not go into the problems connected with measuring and comparing incomes over time. For the specific Dutch situation we can refer to De Kleijn and Van de Stadt (1985) and Grubben (1986a and 1986b). Here we only mention that we have used the pre-tax income for the years 1962 and 1967, the disposable income for the years 1975 and 1981 and both income concepts for the year 1970. In all cases the income of married couples (i.e. the wife's and the husband's income taken together) is the income unit, and therefore the basis for the classification into deciles. Theoretically we would prefer standardized incomes. However, we do not know the distribution of the households by income and number of children. Also the income of children or other household members had to be ignored, because we do not possess the necessary data.

We start with a theoretical discussion (Section 2). In Section 3 we present a number of macro characteristics of married couples in The Netherlands with reference to income and labor force participation by the wives. The Sections 4 and 5 contain our empirical analysis. In the last Section our findings are summarized.

\section{THEORETICAL CONSIDERATIONS}

Economic theory has had little to say specifically about the effect of wives' incomes on the distribution of family earnings. True, in modern microeconomic labor supply theory the wife's participation in the labor market is analysed jointly with other family decision variables and is thus also determined by, for example, the husband's (shadow) wage rate (see e.g. Kapteyn and Woittiez, 1988); the effect on the ultimate distribution of family income, however, has hardly been investigated. The resulting complexity in aggregating individual family incomes to derive the relevant distribution could be one of the reasons for this. So, Gronau concludes that the concerning effect '... depends on the inequality of women's earnings as compared with other sources of income, on the correlation between the two, and on the wife's share in total family income. These in turn depend on participation patterns, the supply of labor, and sex-related wage differentials' and his analysis '.. indicates that it is usually not possible to pinpoint a single factor as the crucial variable'

3 See Netherlands Central Bureau of Statistics (Centraal Bureau voor de Statistiek) (1967a; $1967 \mathrm{~b} ; 1972 \mathrm{a} ; 1972 \mathrm{~b} ; 1977 ; 1979 ; 1980 ; 1982$ and 1985) and Grubben (1985; 1986a and 1986b). 
(Gronau, 1982: 119). We therefore have to limit ourselves to common-sense theoretical considerations.

It is generally assumed that wives' incomes equalize the distribution of family income. According to this view the wife's participation in the labor market compensates for changes in the earnings of other family members (especially the husband) in order to maintain aggregate family income (see e.g. Smith, 1979). Consequently, it is assumed that the wife's labor force participation is negatively related to the husband's income. This is especially true for the years up to about 1970. In the last ten to fifteen years this relationship has weakened, due to the women's movement and efforts to equalize opportunities (Danziger, 1980: 444).

Before that time married women were supposed more likely to work if their husband's earned income (and the income of other household members, if any) was relatively low. Thus, Smith notes that 'wives of more educated men concentrate their market activities during years when the husbands' comparative advantage in market activities is low' (Smith, 1979: S180). This means that working wives were predominantly located in families at the bottom of the income distribution. And this means that the wives' earnings have an inequality-reducing impact (Danziger, 1980: 444 and Thurow, 1976: 5 and 1980: 156).

It would also appear to be a common-sense view to state that, as a consequence of their relatively low labor force participation in the past, women's liberation results in a relatively rapid growth in labor force participation for wives of high-income husbands, so that income inequality should increase relatively (Danziger, 1980: 444 and Thurow, 1980: 161). This increase in income inequality is strengthened by the fact that mating is a selective process.

Another argument is that income inequality amongst women is less unequal than amongst men. All other factors being equal, this means that an increasing labor force participation by wives would reduce inequalities in family incomes.

Why wives' incomes are more equally distributed than those of husbands is not completely clear. To some extent it is a consequence of the underrepresentation of potential high-income earners in the female labor force. But another important cause could be discrimination against females (see Thurow, 1976 and 1980). On the one hand there is wage discrimination. This affects potential high-income earners more than low-income earners. This last group is 'protected' in most developed countries by the existence of a minimum wage system. On the other hand, the wife's career is more frequently interrupted than the husband's (for example, child care is mostly the wife's task). Empirical findings (see e.g. Schmähl, 1983: 17a-17c) show that breaks in employment have a negative effect on income and that the resulting lost ground is not usually recovered. This is also particularly true for higher incomes. This means, however, that 'in a nondiscriminating, equal participation world, female earnings are apt to be as unequal as those of men' (Thurow, 1980: 161). The net result would be a more unequal distribution of household income. 
Recapitulating the above, we get:

1) Women's emancipation leads to a relatively larger labor force participation by wives of high-income-earning husbands. This means, under the assumption that the labor demand for higher educated females is large enough, a growing income inequality;

2) The struggle to achieve a nondiscriminating, equal participation world will lead to a situation in which wives' income inequality does not differ from that of men.

It is not unreasonable to assume that this process has been at work in The Netherlands since the mid-sixties. Because it will take some time before enough women with a high level of education become available for the labor market, it is rational to assume that the process has been affecting income inequality in the described way since about 1970 . We may also assume that, apart from factors in the field of discrimination and emancipation, the factors influencing income inequality among men are at work in the same way for income inequality among women. Examples of this are institutional factors, such as rates of taxation, social security schemes and so on.

The impact of wives' income on family income inequality will be further examined in Section 4. First, we go into the developments in the field of wives' labor force participation and income inequality.

\section{SOME GENERAL CHARACTERISTICS}

Table 1 contains a number of general characteristics of the population under consideration for the period 1962-1981. Row 1 gives the number of married couples with at least one income. Row 2 shows the number of married women with their own income. This includes both wives working outside the home, and those on their husband's payroll. The number of married couples increased from 2.8 million in 1962 to 3.3 million in 1981 . The number of wives with a separate income rose even faster: from almost 500,000 in 1962 to more than 1.3 million in 1981 . This means that the ratio of the number of wives with a separate income to the number of married couples with at least one income has grown. This ratio can roughly be interpreted as being the participation rate of married women in the employed labor force. This rate can be found in row 3. We see that the rate has more than doubled: in 1962 it was 17.8 percent and in 198140.1 percent.

The next part of Table 1 provides information about income. The mean income (not adjusted for inflation) of married couples rose from Dfl. 8,800 in 1962 to Dfl. 17,700 in 1970 (pre-tax income) and from Dfl. 15,200 in 1970 to Dfl. 35,000 in 1981 (disposable income). Looking at the period as a whole, we can conclude that the mean income of households with one income increased somewhat less than that of households in which both husband and wife had an income. The transition from pre-tax to disposable income does not affect the proportions between couples with one and two partners with an income. In 


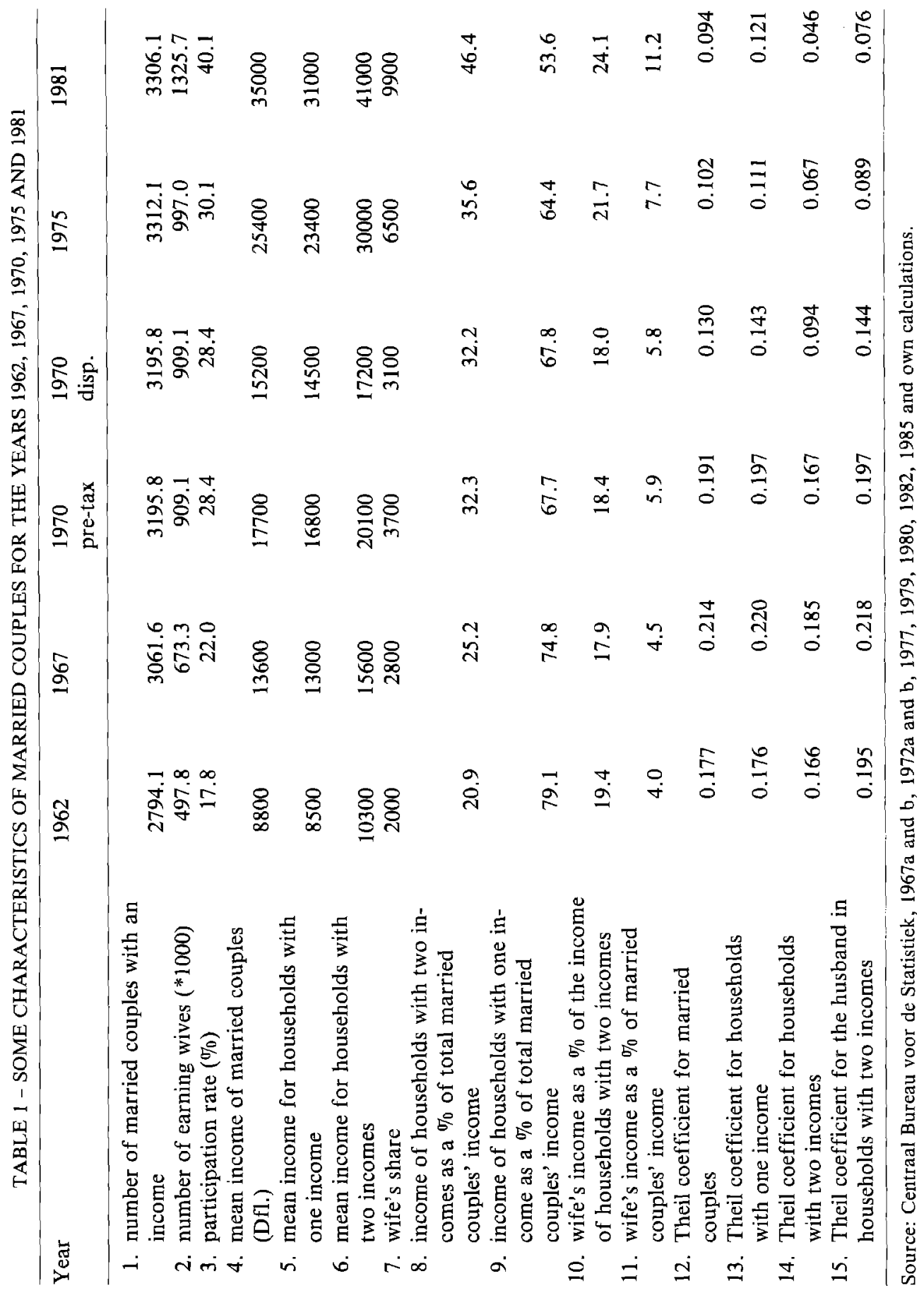


both cases the disposable income amounts to 86 percent of the pre-tax income. Row 7 gives the mean income of the working wife: it increased from Dfl. 2,000 in 1962 to Dfl. 3,700 in 1970 (pre-tax income) and from Dfl. 3,100 in 1970 to Df1. 9,900 in 1981 (disposable income). The proportional change as a consequence of the change-over from pre-tax to disposable income in 1970 (85 percent) nearly equals the change in couples' income. So, the transition hardly influences mean income developments. The rise in the mean income of working wives is substantially larger than the growth in the mean income of couples. In other words, the wife's share of the combined income of husband and wife has increased. The wife's income as a percentage of the income of households with two incomes grew from 19.4 to 24.1 percent (row 10), whereas the figures for the proportion with respect to the total population were 4.0 and 11.2 percent respectively (row 11). The income received by households with respectively two incomes and one income as a percentage of the income of all couples together is given in rows 8 and 9 . In view of the above it will come as no surprise that the proportion of households with two incomes has grown and that this development has been at the expense of households with one income.

The next part of Table 1 gives us information on income inequality by means of the Theil coefficient. The Theil coefficients are calculated on the basis of the division into deciles. We see that the Theil coefficient decreases in all cases during the period 1962-1981. But the decline is not equal for all categories. The biggest decrease (corrected for the conversion from pre-tax income to disposable income) is in the households with two earning partners. Here we note a reduction in the Theil coefficient of about 51 percent. The smallest decline is found in the households with one earning partner (which is usually the husband). Here the decrease is scarcely 5 percent. The drop for all households together was 22 percent, as compared with 47 percent in the husband's income in households with two incomes. The increase between 1962 and 1967 and the rise in the income inequality of households with one earning partner between 1975 and 1981 are the most striking features.

One notable point is that the Theil coefficient of married men whose wives work (row 15) is larger than that of married men whose wives do not work between 1962 and 1970 (row 13). But the difference gets smaller in the course of time and after 1970 the roles are reversed.

The change-over from pre-tax to disposable income in 1970 affects the Theil coefficient for the households with both partners receiving an income heavier than those households with one income. The reduction in income inequality as measured by the Theil coefficient amounts to 44 and 27 percent respectively. It appears that taxes levy wives' income share stronger than husbands' one, which is in accordance with the Dutch tax structure at that time. The change in income concept does not change the proportions between the Theil coefficients for husbands with a partner receiving an income and husbands with a partner receiving no income. So, the reduction in income inequality for households with two incomes, in comparison with households having only one income, can 
completely be ascribed to the changes (due to the transition from pre-tax to disposable income) in the wives' effect on income inequality.

\section{THE WIVES' CONTRIBUTION TOWARDS THE INCOME INEQUALITY OF MARRIED COUPLES}

We have chosen the Theil coefficient as the measure of inequality. This was done because this inequality measure is easily decomposed. Also, the possibilities for interpretation are maintained after the Theil coefficient has been decomposed. We use these properties to determine the wives' contribution towards the income inequality of married couples for the years chosen. ${ }^{4}$ The definition of the Theil coefficient $(T)$ is:

$$
T=\sum_{i=1}^{k} y_{i} * \ln \left(y_{i} / n_{i}\right)
$$

in which $k$ is the number of income groups distinguished, $y_{i}$ is the proportion of income group $i$ in the total income and $n_{i}$ is the number of income earners in income group $i$ as a proportion of the total number of income earners. We now divide the population of married couples into two separate groups: households in which only the husband receives an income and households in which both husband and wife receive an income. We define $Y 1$ as the income of married couples and $Y 2$ as the income of married couples minus the wife's income (in other words: the husband's income). The Theil coefficients corresponding to these income concepts are designated $T 1$ and $T 2$ respectively. Decomposition of the Theil coefficient of $Y 1$ gives:

$$
T l=B I+v_{1} \cdot T I_{w}+\left(1-v_{1}\right) \cdot T I_{n w}
$$

in which $B I$ is the Theil measure of the between-group inequality pertaining to the $Y l$ income concept, $v_{1}$ is the income of couples with two incomes as a proportion of the total income of married couples and $T I_{w}$ and $T I_{n w}$ are the Theil coefficients of households with two incomes and one income respectively.

A similar approach is used to obtain the Theil coefficient $T 2$ applying to the $Y 2$ income concept:

$$
T 2=B 2+v_{2} \cdot T 2_{w}+\left(1-v_{2}\right) \cdot T 2_{n w}
$$

The effect of the wife's income on the income inequality of married couples is given by:

$$
I=T 2-T I
$$

4 See also for example Betson and Van der Gaag (1984), pp. 534-535. 
Since $v_{i}=\mu \cdot \tau_{i}(i=1,2)$, in which $\mu$ is the participation rate of married women in the employed labor force and $\tau_{i}$ is the mean income of households with two incomes as a proportion of the mean income of all couples together and because $T 1_{n w}=T 2_{n w}$, we have:

$$
\begin{aligned}
I & =(B 2-B I)+\mu \cdot\left(\tau_{2} \cdot T 2_{w}-\tau_{1} \cdot T I_{w}\right)+T I_{n w} \cdot \mu \cdot\left(\tau_{1}-\tau_{2}\right) \\
& =Q+\mu \cdot R+T I_{n w} \cdot \mu \cdot S \\
& =Q+R I+S I
\end{aligned}
$$

Here $Q=B 2-B \boldsymbol{I}$ is the change in income inequality between the two groups (i.e. between households with one and two incomes respectively) due to wives' income; $\mu$ is the participation rate of married women in the employed labor force; $R 1=\mu \cdot R=\mu \cdot\left(\tau_{2} \cdot T 2_{w}-\tau_{1} \cdot T 1_{w}\right)$ is the change in the income inequality of households with two incomes as a proportion of the total income inequality of married couples due to wives' income; and $S I=T I_{n w} \cdot \mu \cdot\left(\tau_{1}-\tau_{2}\right)$ is the change in the income inequality of households with one income as a proportion of the total income inequality of married couples due to the income in households with two incomes. There are thus two effects applying to the households with two incomes: the change in the Theil coefficient itself $\left(T 1_{w}\right.$ as compared to $T 2_{w}$ ) and the change in the weight of their contribution towards total income inequality ( $v_{1}$ as compared to $v_{2}$, and hence $\tau_{1}$ as compared to $\tau_{2}$ ). Households with one income are also affected, since the weight of their contribution towards total income inequality is also determined by their income share and this in turn is dependent on wives' income in households with two incomes. This effect is determined by $\left(1-v_{1}\right)$ and $\left(1-v_{2}\right)$ respectively and hence by $\tau_{1}$ as compared to $\tau_{2}$.

The results can be found in Table 2 . Row 8 gives the total effect of working wives on the income inequality of married couples. Factor $I$ always has a positive sign, which means that working wives have an equalizing effect on the income distribution of married couples. At the beginning of the period considered the effect is rather limited, but gradually it increases. In 1962 working wives' income decreases income inequality by about 1.4 percent. By 1967 this figure had risen to 2.5 percent and in 1970 it was 3.2. percent (pre-tax income). The effect of working wives' income on disposable income is larger than on pre-tax income. Switching from pre-tax income to disposable income almost triples the effect: it rises from 3.2 to 8.9 percent. This triplication of the equalizing effect has been caused by four elements. Firstly, the negative effect of $Q$ has somewhat diminished (from -0.0036 to -0.0031 ). Secondly $R$, the change (due to wives' income) in the income inequality of households with two incomes, rises from 0.0052 to 0.0343 . This is in accordance with the changes in the Theil coefficient (due to the change in the income concept) of households with both partners having an income (see Table 1). Thirdly, the $\tau_{i}$ 's change, but their changes are minor. Lastly $T 1_{n w}$ (see Table 1 , line 13) decreases, which 
influences the change in $I$ in a negative way. While the tax structure hardly changed in the period 1962-1970 and the premiums of the social security settlements - introduced during that period - were compensated for, switching from pre-tax income to disposable income will also lead to approximately a triplication of the equalizing effect - as measured by $I / T 2$ - in the years 1962 and 1967.

Between 1970 and 1975 the equalizing effect decreased sharply, and then between 1975 and 1981 we note a further increase. The level for 1981 is almost equal to that of 1970. Up to and including 1970 we see that the growth in the participation rate of married women is accompanied by an equalization of the income distribution, but the increase between 1967 and 1970 is smaller than that between 1962 and 1967. After 1970 the rise in the above participation rate is accompanied by a decline in the extent to which working wives' income decreases income inequality, but between 1975 and 1981 we once more see a growing equalizing influence. Probably, this is stimulated by the shortage of low- and unskilled workers in the 1950's and early 1960's in The Netherlands. This pressure led to large real wage increases and special rises in the minimum wage during a number of years. Besides, the change in the tax system in 1962 made it more attractive for married women to participate. This change implied that wife's earnings were not added anymore to their husband's earnings, but were levied separately. As a consequence the mean tax rate for wife's earnings considerably declined. The combination of the changes in the tax system and the wage increases, especially for lower educated workers, influenced relative prices for market and home production, to the benefit of the first one. Since about 1967, and especially in the 1970's, the demand for low- and unskilled workers, however, declined. Underemployment within this group grew and hit female workers relatively harder than male ones. At the end of the 1970's the difference between unemployment rates for females and males had almost disappeared and unemployment was not only limited to the low- and unskilled workers.

TABLE 2 - THE CONTRIBUTION OF WIVES WITH AN OWN INCOME TOWARDS THE INCOME INEQUALITY OF MARRIED COUPLES

\begin{tabular}{|c|c|c|c|c|c|c|}
\hline & 1962 & 1967 & $\begin{array}{l}1970 \\
\text { pre-tax }\end{array}$ & $\begin{array}{l}1970 \\
\text { disp. }\end{array}$ & 1975 & 1981 \\
\hline 1. $Q$ & -0.0027 & -0.0027 & -0.0036 & -0.0031 & -0.0067 & -0.0081 \\
\hline 2. $\widetilde{\mu}$ & 0.1782 & 0.2199 & 0.2844 & 0.2844 & 0.3010 & 0.4010 \\
\hline 3. $R$ & -0.0045 & 0.0016 & 0.0052 & 0.0343 & 0.0126 & 0.0226 \\
\hline 4. $R I$ & -0.0008 & 0.0004 & 0.0015 & 0.0098 & 0.0038 & 0.0091 \\
\hline 5. $T I_{n w}$ & 0.1764 & 0.2196 & 0.1972 & 0.1426 & 0.1110 & 0.1213 \\
\hline 6. $S$ & 0.1942 & 0.1637 & 0.1495 & 0.1488 & 0.1505 & 0.1666 \\
\hline 7. $S 1$ & 0.0061 & 0.0079 & 0.0084 & 0.0060 & 0.0050 & 0.0081 \\
\hline 8. I & 0.0026 & 0.0055 & 0.0063 & 0.0127 & 0.0021 & 0.0090 \\
\hline \multicolumn{7}{|l|}{ 9. $I / T 2$} \\
\hline$(\%)$ & 1.4 & 2.5 & 3.2 & 8.9 & 2.0 & 8.7 \\
\hline
\end{tabular}


The inequality measures of households with one income and two incomes respectively seemed to be converging, but since 1975 a diverging tendency has been discernible. The development of this difference is expressed by the factors $Q$ and $R$. The between-group inequality $(Q)$ shows the expected picture: as a consequence of the participation of the working wife in the process of income formation, income inequality between households with one income and households with two incomes gets wider. This is caused particularly by the fact that this process further reduces the income inequality between households with two incomes and thus increases the gap between these households and those with one income (for which the income inequality is larger). Developments in the relative share held by the group of households with two incomes $(\tau)$ are negligible.

The factor $R I$ shows a contrasting picture. In 1962 the income of working wives led, via the share held by households with two incomes, to greater income inequality between married couples in terms of total income. After that year we note an equalizing effect. However, between 1970 and 1975 the degree of equalization becomes temporarily smaller.

The effect of wives with sources of income on the share held by households with one income in income inequality $(S 1)$ is an equalizing one: as a consequence of the wives' income the income of households with two incomes as a proportion of total income has risen at the expense of the income of households with one income. Therefore the larger income inequality of the latter group counts for less in the total income inequality of married couples. Developments in $S I$ are, however, unpredictable (as a consequence of the developments in $T 1_{n w}$ and $S$ ), but the changes are rather minor.

Summarizing we can say that the income of earning wives has an income equalizing effect. But the extent to which it equalizes income is not constant during the period under investigation. Between 1962 and 1970 we observe a growing equalizing effect, between 1970 and 1975 a declining equalizing effect, whereas the effect increases again between 1975 and 1981. As is to be expected, it is mainly the income inequality of the group of households with two incomes which is the major factor. The effect exerted through between-group inequality, however, must not be neglected. Although it is true that the effect due to the income inequality of households with one income is large (in absolute terms), this effect is relatively less important in explaining the observed changes, because of its stable character.

We must also note that the above is only true if we assume that there are no consequences when the wife stops working and earning money. If there are consequences, however, then the equalizing effect will be larger, given the development in the Theil coefficients. For example, it is quite conceivable that in that case the income distribution of men whose wives are currently earning an income would shift towards the distribution of men whose wives have no income. There would then still be an equalizing effect (see rows 12 and 13 in Table 1); indeed, the effect would actually be greater! In the extreme situation, 
where the income distribution of married couples with two incomes shifted towards that of households with one income, the equalizing effect in 1962 would hardly change, in 1967 it would be 0.2 percent more, in 19700.3 (pre-tax income) and 0.9 percent (disposable income), in 19750.9 and in 1981 as much as 2.6 percent.

\section{A FURTHER ANALYSIS OF THE CHANGES IN THE PERIOD 1962-1981}

The Theil coefficient's property of being decomposable enables us to analyse developments in the course of time more extensively. For this purpose we rewrite ${ }^{5}$ equation (2) to obtain (6):

$$
\begin{aligned}
T= & \mu \cdot \tau_{w} \cdot \ln \left(\tau_{w}\right)+\left(1-\mu \cdot \tau_{w}\right) \cdot \ln \left(\left(1-\mu \cdot \tau_{w}\right) /(1-\mu)\right)+ \\
& \mu \cdot \tau_{w} \cdot T_{w}+\left(1-\mu \cdot \tau_{w}\right) \cdot T_{n w}
\end{aligned}
$$

Just as we defined the mean income of households with two incomes as a proportion of the income of all married couples together, we can define $\left(1-\mu \cdot \tau_{w}\right) /(1-\mu)$ as the mean income of households with one income as a proportion of the mean income of all married couples together. We thus designate this factor by $\tau_{n w}$. The first two components on the right-hand side of equation (6) account for the between-group inequality, whereas the latter two indicate the effect of the within-group inequality. Applying the difference operator to equation (6) and in each case taking the mean over the two years (the base and final period values respectively) for the aggregation weights, we then get:

$$
\begin{aligned}
T= & T\left(t_{1}\right)-T\left(t_{0}\right) \\
= & \Delta\left(\mu \cdot \tau_{w} \cdot T_{w}+\left(1-\mu \cdot \tau_{w}\right) \cdot T_{n w}\right)+ \\
& \Delta\left(\mu \cdot \tau_{w} \cdot \ln \left(\tau_{w}\right)+\left(1-\mu \cdot \tau_{w}\right) \cdot \ln \left(\tau_{n w}\right)\right) \\
= & \overline{\mu \cdot \tau_{w}} \cdot \Delta T_{w}+\overline{\left(1-\mu \cdot \tau_{w}\right)} \cdot \Delta T_{n w} \\
& +\overline{T_{w}} \cdot \Delta\left(\mu \cdot \tau_{w}\right)+\overline{T_{n w}} \cdot \Delta\left(1-\mu \cdot \tau_{w}\right) \\
& +\overline{\ln \left(\tau_{w}\right)} \cdot \Delta\left(\mu \cdot \tau_{w}\right)+\overline{\ln \left(\tau_{n w}\right)} \cdot \Delta\left(1-\mu \cdot \tau_{w}\right)
\end{aligned}
$$

Part I of equation (7) can be interpreted as the impact of changes in the withingroup inequality; parts II and III indicate the effect of changes in the population proportions on the within-group and between-group components, respec-

5 See Mookherjee and Shorrocks (1982). For the sake of simplicity we have ignored the index 1 (indicating that we use the income concept $\mathrm{Y} 1$, the income of married couples, including the wives' income). 
tively; and part IV can be interpreted as the effect of changes in the relative income of the subpopulations distinguished and hence as the effect of the changes in the elements of between-group inequality. Thus, parts I and IV give the impact of the changes in the elements which form the Theil coefficient, whereas parts II and III represent the effect of the changes in the weights of the elements.

The contribution of each of the factors to the total change in the inequality measure is given in Table 3. It is clear from this table that the changes in the Theil coefficient are mainly determined by the changes in within-group inequality (part I). The effect of the income shares of the subpopulations due to within-group inequality (part II) is somewhat less marked. On the other hand, the effect of the income shares due to the between-group component (part III) is large, though this is completely compensated for (when we consider the period as a whole) by the changes in the elements which determine betweengroup inequality (part IV).

Looking at the effect of the within-group component, we see that the proportion of households with one income is larger than that of households with two incomes up to and including 1975. After that year the reverse applies. The afore-mentioned increase in income inequality in the group of households with one income between 1975 and 1981 also emerges. The relative proportion of households with one income contributing towards the total (equalizing) effect

TABLE 3 - THE DECOMPOSITION OF THE CHANGES IN INCOME INEQUALITY INTO FOUR PARTS

\begin{tabular}{|c|c|c|c|c|c|c|}
\hline \multicolumn{2}{|c|}{$\begin{array}{l}\text { receiving } \\
\text { an income }\end{array}$} & $\begin{array}{l}1967 \\
\text { to } \\
1962\end{array}$ & $\begin{array}{l}1970 \\
\text { to } \\
1967\end{array}$ & $\begin{array}{l}1975 \\
\text { to } \\
1970\end{array}$ & $\begin{array}{l}1981 \\
\text { to } \\
1975\end{array}$ & $\begin{array}{l}1981 \\
\text { to } \\
1962\end{array}$ \\
\hline I & $\begin{array}{l}\text { both partners } \\
\text { one partner } \\
\text { total }\end{array}$ & $\begin{array}{l}0.004 \\
0.033 \\
0.038\end{array}$ & $\begin{array}{l}-0.005 \\
-0.016 \\
-0.021\end{array}$ & $\begin{array}{l}-0.009 \\
-0.021 \\
-0.030\end{array}$ & $\begin{array}{r}-0.009 \\
0.006 \\
-0.003\end{array}$ & $\begin{array}{r}-0.019 \\
0.002 \\
-0.017\end{array}$ \\
\hline II & $\begin{array}{l}\text { both partners } \\
\text { one partner } \\
\text { total }\end{array}$ & $\begin{array}{r}0.008 \\
-0.009 \\
-0.001\end{array}$ & $\begin{array}{r}0.013 \\
-0.015 \\
-0.002\end{array}$ & $\begin{array}{r}0.003 \\
-0.004 \\
-0.002\end{array}$ & $\begin{array}{r}0.006 \\
-0.013 \\
-0.007\end{array}$ & $\begin{array}{r}0.030 \\
-0.041 \\
-0.012\end{array}$ \\
\hline III & $\begin{array}{l}\text { both partners } \\
\text { one partner } \\
\text { total }\end{array}$ & $\begin{array}{l}0.006 \\
0.002 \\
0.008\end{array}$ & $\begin{array}{l}0.009 \\
0.003 \\
0.013\end{array}$ & $\begin{array}{l}0.005 \\
0.002 \\
0.007\end{array}$ & $\begin{array}{l}0.017 \\
0.010 \\
0.027\end{array}$ & $\begin{array}{l}0.037 \\
0.017 \\
0.055\end{array}$ \\
\hline IV & $\begin{array}{l}\text { both partners } \\
\text { one partner } \\
\text { total }\end{array}$ & $\begin{array}{l}-0.005 \\
-0.003 \\
-0.008\end{array}$ & $\begin{array}{l}-0.002 \\
-0.011 \\
-0.012\end{array}$ & $\begin{array}{r}0.016 \\
-0.019 \\
-0.003\end{array}$ & $\begin{array}{l}-0.009 \\
-0.017 \\
-0.026\end{array}$ & $\begin{array}{r}0.000 \\
-0.050 \\
-0.049\end{array}$ \\
\hline$\Delta T$ & & 0.037 & -0.023 & -0.028 & -0.008 & -0.022 \\
\hline
\end{tabular}


therefore decreases. This is a consequence of, among other things, the change in these households' income as a proportion of the total income of married couples. This is chiefly caused by the increased labor force participation of married women and is less dependent on the mean income of households with one income as a percentage of that of households with two incomes.

The overall effect of the changes in the income share due to the within-group component is small, but its components (households with one and two incomes) may have high values. While the (absolute) changes in the income share of the two groups are equal (and differ only in sign) and the differences in the Theil coefficients of both groups are relatively small, the net effect is small. It is slightly negative, which means that the changes in the income shares have a small equalizing effect due to the within-group components in the period 1962-1981. This stands to reason because there is a 'transfer' from the income share of households with one income to that of households with two incomes and the income inequality for the latter group is less than for the former.

For the effect of the income shares due to the between-group components, the changes in the income shares are the same for both groups (apart from the sign), but the income factors that determine the between-group inequality $\left[\ln \left(\tau_{w}\right)\right.$ and $\left.\ln \left(\tau_{n w}\right)\right]$ differ heavily. The net effect is positive, which means that the change in the income shares has strongly increased income inequality. This is caused by the fact that there is a transfer in the income shares in favour of the group that makes the largest contribution to the between-group inequality, viz. the households with two incomes.

Finally, we come to the changes in the relative income of the subpopulations distinguished. These form the basis of the size of the between-group inequality. Because they have converged there is a very strong equalizing impact from this element.

When comparing the results, we must take into account the change-over from pre-tax income to disposable income in 1970. The total effect of the change-over approximately results in a decline of $T$ by 0.060 . This decrease mainly results from changes in part I of equation (7). Consequently, the effect between 1967 and 1970 equals the effect between 1970 and 1975, and speaking in terms of disposable income, the size of $\Delta T$ will probably amount to about 0.030 between 1962 and 1967.

If we combine the results from Table 3 with those from the last section then it is possible to determine the extent to which the change in income inequality of wives with an income deviates from that of all married couples. For this purpose Table 4 gives the change in the Theil coefficient for married couples $(\Delta T$, or, strictly speaking, $\Delta T 1$ in terms of the last section) and the change in the Theil coefficient for husbands (i.e. with the wives' income excluded, $\Delta T 2$ ). The difference between these two values can be interpreted as the extent to which changes in wives' income have influenced the equalizing effect of this income on the distribution of the income of married couples. When the difference is positive the equalizing effect of wives' income has grown and when it is 
negative the influence is less equalizing than before. As we saw in the preceding section, the wives with earnings generally have a growing equalizing effect on the income distribution. However, between 1970 and 1975 we see that the equalization of income was slowing down. As a result, the extent to which wives' income equalizes family income inequality is only slightly more in 1981 than in 1962.

\section{RÉSUMÉ}

In this article we have looked at the importance of wives' incomes for the income distribution of married couples. ${ }^{6}$ The analysis shows that their income has an equalizing effect. The extent to which this applies, however, differs from period to period. Between 1970 and 1975 we note a particular stagnation. During this period it even had a negative effect on developments in the income inequality of married couples. Bearing in mind behavioural reactions that might result when the wife no longer has an income, then the equalizing effect is underestimated.

The other side of the coin is that the income inequality for men with an earning wife is much lower than that for men whose wives do not have any income. The difference between these two groups is growing during the whole period.

From the point of view of policy this is an important conclusion. In the discussion of income equalizing trends in The Netherlands (and also other countries), the effect of the increased labor force participation of married women is ignored. It is reasonable to ask whether this is justified. This element of income equalization is a consequence of a desirable policy (among other things from the point of view of emancipation) and not directly (though possibly indirectly) a consequence of changes in the primary and secondary income distribution of individuals. This supports the need for a correction for

TABLE 4 - THE EFFECT OF CHANGES IN THE INCOME DISTRIBUTION OF WIVES WITH AN INCOME ON DEVELOPMENTS IN THE INCOME INEQUALITY OF MARRIED COUPLES

\begin{tabular}{|c|c|c|c|c|c|}
\hline Year & $\begin{array}{l}1967 \\
\text { to } \\
1962\end{array}$ & $\begin{array}{l}1970 \\
\text { to } \\
1967\end{array}$ & $\begin{array}{l}1975 \\
\text { to } \\
1970\end{array}$ & $\begin{array}{l}1981 \\
\text { to } \\
1975\end{array}$ & $\begin{array}{l}1981 \\
\text { to } \\
1962\end{array}$ \\
\hline $\begin{array}{l}\Delta T 2 \\
\Delta T\end{array}$ & $\begin{array}{l}0.040 \\
0.037\end{array}$ & $\begin{array}{l}-0.022 \\
-0.023\end{array}$ & $\begin{array}{l}-0.039 \\
-0.028\end{array}$ & $\begin{array}{l}-0.001 \\
-0.008\end{array}$ & $\begin{array}{l}-0.022 \\
-0.022\end{array}$ \\
\hline$\Delta T 2-\Delta T$ & 0.003 & 0.001 & -0.011 & 0.007 & 0.001 \\
\hline
\end{tabular}

6 The picture hardly changes when we include cohabitation in the analysis; see Grubben (1986b), p. 22. 
this effect when considering the developments in income inequality (and precisely with reference to the desired income equalization or possibly desired increase in income inequality). ${ }^{7}$ In that case the (corrected) income equalization for the last few decades would be considerably less then is assumed nowadays.

\section{REFERENCES}

Bergmann, B.R., J. Radlinski Devine, P. Gordon, D. Reedy, L. Sage and C. Wise (1980), 'The Effect of Wives' Labor Force Participation on Inequality in the Distribution of Family Income,' Journal of Human Resources, 15, pp. 452-455.

Betson, D. and J. Van der Gaag (1984), 'Working Married Women and the Distribution of Income,' Journal of Human Resources, 19, pp. 532-543.

Centraal Bureau voor de Statistiek (1967a), Inkomensverdeling van gezinnen 1962, The Hague.

Centraal Bureau voor de Statistiek (1967b), Inkomensverdeling van werkende gehuwde vrouwen 1962, The Hague.

Centraal Bureau voor de Statistiek (1972a), Inkomensverdeling van werkende gehuwde vrouwen 1967, The Hague.

Centraal Bureau voor de Statistiek (1972b), Inkomensverdeling 1967 en Vermogensverdeling 1968, The Hague.

Centraal Bureau voor de Statistiek (1977), Inkomensverdeling 1970 en Vermogensverdeling 1971, The Hague.

Centraal Bureau voor de Statistiek (1979), Inkomensverdeling van werkende gehuwde vrouwen 1970 en 1973, The Hague.

Centraal Bureau voor de Statistiek (1980), De personele inkomensverdeling 1975; deel I, The Hague.

Centraal Bureau voor de Statistiek (1982), De personele inkomensverdeling; werkende gehuwde vrouwen 1975 en 1976 , The Hague.

Centraal Bureau voor de Statistiek (1985), Personele inkomensverdeling 1981, individuen, The Hague.

Danziger, S. (1980), 'Do Working Wives Increase Family Income Inequality?,' Journal of Human Resources, 15, pp. 444-451.

Gronau, R. (1982), 'Inequality of Family Income: Do Wives' Earnings Matter?,' Population and Development Review, 8 (Suppl.), pp. 119-136.

Grubben, B. (1985), 'Aandelen van leden van huishoudens in het huishoudensinkomen,' Supplement bij de Sociaal-economische Maandstatistiek, 1985/8, pp. 22-40.

Grubben, B. (1986a), 'Inkomens van gezinnen in 1962 en 1981,' Supplement bij de Sociaaleconomische Maandstatistiek, 1986/1, pp. 24-40.

Grubben, B. (1986b), 'Inkomens van gezinnen in 1962 en 1981: werkende gehuwde vrouwen,' Supplement bij de Sociaal-economische Maandstatistiek, 1986/3, pp. 11-23.

Kam, C.A. de, E.J. Pommer and C.J. Wiebrens (1982), 'Dubbel en dwars over dubbele inkomens in 1979,' Economisch Statistische Berichten, 67, pp. 1040-1047.

7 The same probably holds for the effect of the changing age structure of the population. See also Mookherjee and Shorrocks (1982). 
Kapteyn, A. and I. Woittiez (1988), 'Preference Interdependence and Habit Formation in Family Labor Supply,' in: F. Laisney, et al (eds), Contributions to Applied Microeconometrics, Clevedon, Avon.

Kleijn, J.P. de and H. Van de Stadt (1985), 'Ontwikkelingen in de inkomensverdeling sinds 1970,' Economisch Statistische Berichten, 70, pp. 1004-1009.

Mookherjee, D. and A. Shorrocks (1982), 'A Decomposition Analysis of the Trend in UK Income Inequality, Economic Journal, 92, pp. 886-902.

Odink, J.G. (1985), Inkomensherverdeling; enkele aspecten van de inkomensherverdeling door de overheid in Nederland, Groningen.

Odink, J.G. and H.A. Pott-Buter (1982), 'Inkomensverdeling en de fiscale emancipatie van de gehuwde vrouw,' Maandschrift Economie, 46, pp. 276-297.

Schmähl, W. (1983), Income Analysis Based on Longitudinal Data from Social Security Records: The Relative Earnings Position (Age-Earnings Profile) and the Individual Replacement Rate of German Workers, Sfb-3 Arbeitspapier Nr. 92, Frankfurt/Mannheim.

Smith, J.P. (1979), 'The Distribution of Family Earnings,' Journal of Political Economy, 87, pp. S163-S192.

Sweet, J.A. (1980), 'The Employment of Wives and the Inequality of Family Income,' in: A.H. Amsden (ed.), The Economics of Women and Work, Harmondsworth, pp. 400-409.

Thurow, L.C. (1975), Lessening Inequality in the Distribution of Earnings and Wealth, unpublished paper presented for the Institute of Advanced Study, Princeton, N.J.

Thurow, L.C. (1976), Generating Inequality, London.

Thurow, L.C. (1980), The Zero-Sum Society, New York.

\section{Summary}

\section{THE EFFECT OF INCREASED LABOR FORCE PARTICIPATION OF MARRIED WOMEN ON THE DISTRIBUTION OF FAMILY INCOME IN THE NETHERLANDS}

In this article we analyse the income equalizing effect of wives' income on the combined income of husband and wife in The Netherlands. We will use the Theil coefficient as a measure of inequality. After some preliminary remarks have been made and relevant data have been presented, the Theil coefficient is decomposed into a number of components. Whereas theory concludes that the effect of wives' income on the distribution of family income should be less equalizing after about 1970, it appears that this does not hold true for the whole period under investigation. 